Article

\title{
Reversal of Multidrug Resistance in Human Colon Cancer and Human Leukemia Cells by Three Plant Extracts and Their Major Secondary Metabolites
}

\author{
Jun-Xian Zhou and Michael Wink*D \\ Institute of Pharmacy and Molecular Biotechnology, Heidelberg University, Im Neuenheimer Feld 364, \\ 69120 Heidelberg, Germany; junxian.zhou@stud.uni-heidelberg.de \\ * Correspondence: wink@uni-heidelberg.de; Tel.: +49-(0)6221-544884
}

Received: 15 October 2018; Accepted: 11 November 2018; Published: 13 November 2018

\begin{abstract}
Background: We studied the effect of three plant extracts (Glycyrrhiza glabra, Paeonia lactiflora, Eriobotrya japonica) and six of their major secondary metabolites (glycyrrhizic acid, $18 \beta$ glycyrrhetinic acid, liquiritigenin, isoliquiritigenin, paeoniflorin, ursolic acid) on the multidrug resistant human colon cancer cell line Caco-2 and human leukemia cell line CEM/ADR 5000 as compared to the corresponding sensitive cell line CCRF-CEM, and human colon cancer cells HCT-116, which do not over-express ATP-binding cassette (ABC) transporters. Methods: The cytotoxicity of single substances in sensitive and resistant cells was investigated by MTT assay. We also applied combinations of extracts or single compounds with the chemotherapeutic agent doxorubicin or doxorubicin plus the saponin digitonin. The intracellular retention of the $\mathrm{ABC}$ transporter substrates rhodamine 123 and calcein was examined by flow cytometry to explore the effect of the substances on the activity of $A B C$ transporters P-glycoprotein and MRP1. Real-time PCR was applied to analyse the gene expression changes of ABCB1, ABCC1, caspase 3, caspase 8, AhR, CYP1A1, and GSTP1 in resistant cells under the treatment of the substances. Results: All the substances moderately inhibited cell growth in sensitive and resistant cells to some degree. Whereas ursolic acid showed $\mathrm{IC}_{50}$ of 14 and $22 \mu \mathrm{M}$ in CEM/ADR 5000 and Caco- 2 cells, respectively, glycyrrhizic acid and paeoniflorin were inactive with $\mathrm{IC}_{50}$ values above $400 \mu \mathrm{M}$. Except for liquiritigenin and isoliquiritigenin, all the other substances reversed MDR in CEM/ADR 5000 and Caco-2 cells to doxorubicin. Ue, ga, 18ga, and urs were powerful reversal agents. In CEM/ADR 5000 cells, high concentrations of all the substances, except Paeonia lactiflora extract, increased calcein or rhodamine 123 retention in a dose-dependent manner. In Caco-2 cells, all the substances, except liquiritigenin, retained rhodamine 123 in a dose-dependent manner. We also examined the effect of the plant secondary metabolite (PSM) panel on the expression of ABCB1, ABCC1, caspase 3, caspase 8, AhR, CYP1A1, and GSTP1 genes in MDR cells. Conclusions: The extracts and individual PSM could reverse MDR in CEM/ADR 5000 and Caco-2 cells, which overexpress ABC transporters, in two- and three-drug combinations. Most of the PSM also inhibited the activity of $\mathrm{ABC}$ transporters to some degree, albeit at high concentrations. Ue, ga, 18ga, and urs were identified as potential multidrug resistance (MDR) modulator candidates, which need to be characterized and validated in further studies.
\end{abstract}

Keywords: multidrug resistance (MDR); plant extracts; plant secondary metabolite (PSM); $\mathrm{ABC}$ transporter

\section{Introduction}

Cancer cells are often found to develop resistance to anticancer drugs, not only to a single or a group of drugs, but also to many other structurally and functionally unrelated drugs, even if the cells have never been exposed to the other drugs. This is called multidrug resistance (MDR), which is a key 
reason of chemotherapy failure in various cancers [1,2]. Three major mechanisms have been implicated in MDR: (1) decreased uptake of transporter-dependent hydrophilic drugs into cells; (2) various cellular changes that reduce drug toxicity and promote cell survival opportunities, for example, altered by drug metabolism, and decreased apoptosis; and (3) an increased drug efflux, mediated mainly by ATP-binding cassette (ABC) transporters [3]. Recent studies suggested some new mechanisms for MDR, for example, cell-cell interactions, mechanotransduction, lysosomal drug sequestration, and so on $[4,5]$.

Export of hydrophobic drugs by ABC transporters across the cell membrane, using the energy of ATP binding, reduces the total intracellular drug concentration, or these transporters redirect the cytotoxic drugs away from target organelles [6]. P-glycoprotein (P-gp, MDR1 or ABCB1) and multidrug resistance-associated protein (MRP) were the earliest identified $A B C$ transporters $[7,8]$. Their over-expression contributes to the MDR phenotype of cancer cells [9]. Cancer cells can develop resistance towards apoptosis, the execution of which requires caspases (caspase 3, 8, 9, etc.), and this capability_evading apoptosis_-is a hallmark of cancer [10-12]. Besides reduced apoptosis, altered metabolism of drugs can also influence MDR. The aryl hydrocarbon receptor (AhR) is a transcription factor which regulates phase I (cytochrome P450, CYPs) and phase II metabolic enzyme (microsomal epoxide hydrolases, glutathione S-transferases (GSTs), sulfotransferases) expressions [13,14]. Many anticancer drugs undergo CYP-mediated metabolism and excretion and thus lose their efficacy [15]. One of the phase II metabolic enzyme GSTs, GSTpi, is involved in the conjugation reactions of drugs in many different tumors [16], and its expression level is often high in MDR cancer cells [17].

Chemotherapeutic agents such as doxorubicin often show a general high toxicity and thus limited efficacy [18]. Drug combinations may improve their efficacy, and even show synergistic effects [19]. The steroidal saponin digitonin and other saponins can increase the permeability of cell membranes [20] and may generate synergism in drug combinations. Some plant extracts and their secondary metabolites (PSM) can inhibit ABC transporter and reverse MDR [21]. Here, three plant extracts from Traditional Chinese Medicine (TCM), the root extracts of Glycyrrhiza glabra, Paeonia lactiflora (mixed with Paeonia veitchii), and the leaf extract of Eriobotrya japonica and six of their major secondary metabolites (glycyrrhizic acid, $18 \beta$ glycyrrhetinic acid, liquiritigenin, and isoliquiritigenin from G. glabra, paeoniflorin from P. lactiflora, and ursolic acid from E. japonica) were investigated as potential substrates for ABC transporters and modulators of MDR.

Glycyrrhiza glabra (Fabaceae) root has been used in traditional medicine in Europe and Asia for thousands of years $[22,23]$ to treat hepatitis $C$, inflammation, and other health conditions. It possesses anti-inflammatory, anticancer, antiviral, antimicrobial, antitussive, expectorant, and other biological activities [24,25]. Paeonia lactiflora (Paeoniaceae) is an ornamental garden plant and used in traditional medicine, especially in Traditional Chinese Medicine [23]. Depending on the processing of roots, two kinds of herbal medicines are on the market: white dried root without bark mainly originates from Paeonia lactiflora, while red dried root with bark originates from P. lactiflora or P. veitchii [26]. Paeonia lactiflora extract has anti-inflammatory, antiviral, anticancer, and antibacterial effects [27]. Paeonia veitchii was found to have activities against enterovirus infections [28]. Eriobotrya japonica (Rosaceae) is a traditional medicine plant used to treat cough and as an expectorant. It has anti-inflammatory and anti-diabetic properties [29].

The six main secondary metabolites from the three TCM plants possess various pharmacological activities. The triterpenoid saponin glycyrrhizic acid showed anti-cancer and anti-inflammatory activities [30-32]. 18 $\beta$ Glycyrrhetic acid is the aglycone of glycyrrhizic acid; it exhibits anti-malarial and anti-inflammatory effects, and excellent anticancer potential in some cancer cells [33-35]. Liquiritigenin, a major flavonoid of G. glabra, possesses antitumor, anti-inflammatory, and neuroprotective effects [36,37]. The flavonoid isoliquiritigenin has antiproliferative ability in cancer cells [38-40]. The content of the monoterpene paeoniflorin in P. lactiflora is above 1.6\% [27]. Paeoniflorin exhibits anti-inflammatory, immunoregulatory, neuroprotective, and anti-cancer properties [41-44]. Ursolic acid, a pentacyclic triterpenoid in E. japonica and widely distributed in various plants [45], has a wide spectrum of 
pharmacological activities, for example, antimutagenic, and anti-cancer activities $[46,47]$. The structures of the compounds are shown in Figure 1.

We investigated the influence of the three plant extracts and six major PSM from them (Figure 1) on the MDR cancer cells CEM-ADR 5000 and Caco-2 as compared to the sensitive CCRF-CEM and HCT-116 cells and explored their possible mechanisms. Of special interest was the ability of the PSM panel to exert synergistic MDR reversal for doxorubicin in two- and three-drug combinations. We focused on the modulation of $\mathrm{ABC}$ transporters, apoptosis and drug metabolism. In this context, we analysed expression changes of ABCB1, ABCC1, caspase 3, caspase 8, AhR, CYP1A1, and GSTP1 genes in resistant cells after the treatment with plant extracts and secondary metabolites.<smiles>COc1cccc2c1C(=O)c1c(O)c3c(c(O)c1C2=O)C[C@@](O)(C(=O)CO)C[C@H]3O[C@@H]1C[C@@H](N)[C@H](O)[C@H](C)O1</smiles>

Doxorubicin (Dox)<smiles>O=C1C[C@H](c2ccc(O)cc2)Oc2cc(O)ccc21</smiles>

Liquiritigenin (liq)

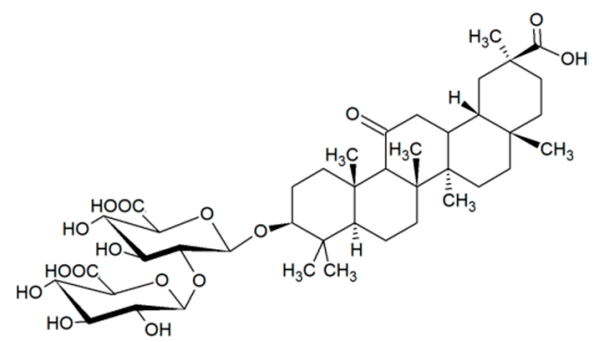

Glycyrrhizic acid (ga)

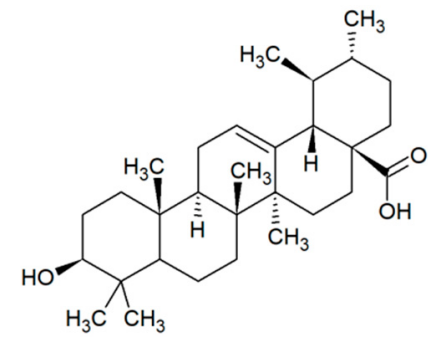

Ursolic acid (urs)

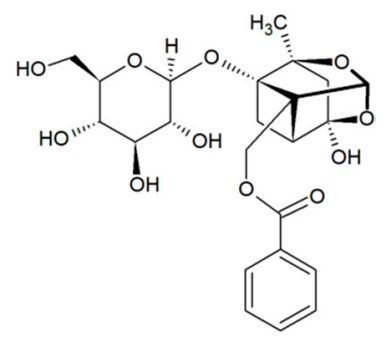

Paeoniflorin (pae)<smiles>O=C(/C=C/c1ccc(O)cc1)c1ccc(O)cc1O</smiles>

Isoliquiritigenin (iso)

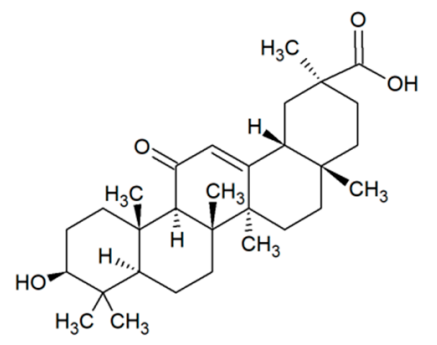

Glycyrrhetinic acid (18ga)<smiles>COc1ccc(CCN(C)CCCC(C#N)(c2ccc(OC)c(OC)c2)C(C)C)cc1OC</smiles>

Verapamil (Ver)

Figure 1. Cont. 


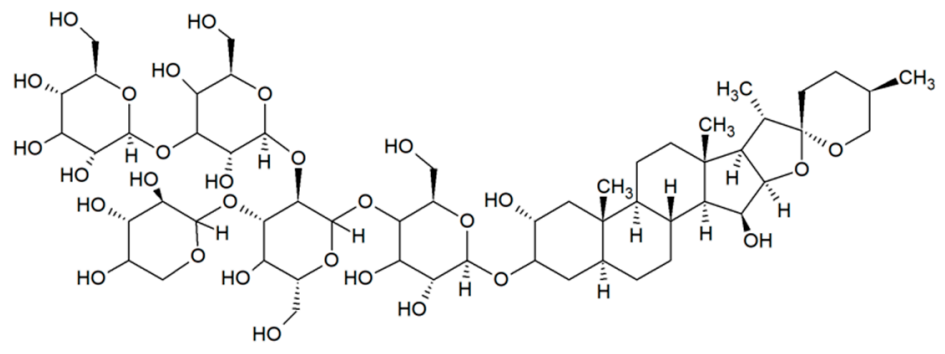

Digitonin (Dig)

Figure 1. Chemical structures of compounds (and their abbreviations) used in this study.

\section{Materials and Methods}

\subsection{Materials}

Glycyrrhiza glabra was purchased from Caesar \& Lorentz GmbH (Hilden, Germany). Paeonia lactiflora was bought with Paeonia veitchii as a mixture in a pharmacy in China. Eriobotrya japonica was obtained from Kräuter Schulte (Gernsbach, Germany). Human T lymphoblast CCRF-CEM and leukaemia cell line CEM/ADR 5000 were kindly provided by Professor Dr. Thomas Efferth (Institute of Pharmacy and Biochemistry, University of Mainz, Mainz, Germany). Human colon cancer cells HCT-116 were obtained from Professor Dr. Stefan Wölfl (Institute of Pharmacy and Molecular Biotechnology, Heidelberg University, Heidelberg, Germany). Human epithelial colorectal adenocarcinoma cells Caco-2 were bought from the German Collection of Microorganisms and Cell Cultures (DSMZ, Braunschweig, Germany).

The 3-(4,5-Dimethylthiazol-2-yl)-2,5-diphenyltetrazolium bromide (MTT), doxorubicin, and verapamil were bought from Sigma-Aldrich (Darmstadt, Germany). Digitonin was from Carl Roth (Karlsruhe, Germany). Glycyrrhizic acid, $18 \beta$ glycyrrhetinic acid, isoliquiritigenin, liquiritigenin, paeoniflorin, ursolic acid were obtained from Baoji Herbest Bio-Tech (Baoji, China).

\subsection{Plant Extraction}

The dried roots of Glycyrrhiza glabra, Paeonia lactiflora, and the dried leaves of Eriobotrya japonica were powdered and immediately extracted using ultrasound with $100 \%$ methanol (for G. glabra), 50\% ethanol (for P. lactiflora), and $96 \%$ ethanol (for E. japonica), respectively, at room temperature for $50 \mathrm{~min}$. After cooling down, the extracts were centrifuged at $4000 \mathrm{rpm}$ for $12 \mathrm{~min}$ and filtered. The solvent was freeze dried and the dry extracts of Glycyrrhiza glabra $(\mathrm{Ge})$, Paeonia lactiflora $(\mathrm{Pe})$ and Eriobotrya japonica (Ue) were stored at $4{ }^{\circ} \mathrm{C}$ for use.

\subsection{Cell Culture and Viability by MTT Assay}

Suspension cells (CCRF-CEM and CEM/ADR 5000 cells) were cultured in RPMI 1640 media containing 10\% FBS, $100 \mathrm{U} / \mathrm{mL}$ penicillin-streptomycin and $2 \mathrm{mM}$ L-glutamine. Adherent cells (Caco-2 and HCT-116 cells) were cultured in DMEM containing $10 \% \mathrm{FBS}, 100 \mathrm{U} / \mathrm{mL}$ penicillin-streptomycin and $2 \mathrm{mM}$ L-glutamine. All cells were incubated at $37{ }^{\circ} \mathrm{C}$ with $5 \% \mathrm{CO}_{2}$.

The MTT assay was modified from Mosmann [48]. For the adherent cells Caco-2 and HCT-116, cells with a density of $6 \times 10^{4}$ were seeded in 96-well plates and incubated for $24 \mathrm{~h}$ at $37^{\circ} \mathrm{C}$. Media were removed and various doses of substances prepared in media were added to the plates and incubated for $24 \mathrm{~h}$ (for HCT-116 cells) or $48 \mathrm{~h}$ (Caco-2 cells). Then media were removed, and $0.5 \%$ MTT (dissolved in media) was added and further incubated at $37^{\circ} \mathrm{C}$ for $2-4 \mathrm{~h}$. Subsequently, the plates were centrifuged at $400 \mathrm{rpm}$ for $10 \mathrm{~min}$, and the absorption was read at $570 \mathrm{~nm}$ with the Tecan Nano Quant infinite M200 PRO Plate Reader (Tecan, Männedorf, Switzerland).

For the suspension cells CCRF-CEM and CEM/ADR 5000, cells with a density of $30 \times 10^{4}$ were seeded in 96-well plates, and various doses of substances were added. The plates were incubated for $48 \mathrm{~h}$, and MTT was added to a final concentration of $0.5 \%$ and further incubated for $2-4 \mathrm{~h}$. 
The incubation was terminated, plates were centrifuged for $10 \mathrm{~min}$, and the absorption was read at $570 \mathrm{~nm}$ using the Tecan Nano Quant infinite M200 PRO Plate Reader. Doxorubicin was used as a positive control.

\subsection{Effect of Two- and Three-Drug Combinations on Cell Viability}

A non-cytotoxic dose (below $\mathrm{IC}_{30}$ ) of a single plant extract or secondary metabolite was added together with different concentrations of the chemotherapeutic agent doxorubicin (two-drug combination) or doxorubicin plus $0.5 \mu \mathrm{M}$ digitonin (three-drug combination). The MTT assay was used to test whether the test compounds can increase the sensitivity of CEM/ADR 5000 cells and Caco- 2 cells to doxorubicin. We compared the $\mathrm{IC}_{50}$ of doxorubicin in drug combinations with the $\mathrm{IC}_{50}$ of doxorubicin applied alone.

\subsection{ABC Transporter Assay with the Substrate Calcein-AM in CCRF-CEM and CEM/ADR5000 Cells}

Calcein-acetoxymethyl ester (calcein AM) and rhodamine 123 (rho 123) are nontoxic, fluorescent dyes and substrates of P-gp and MRP1. By measuring their cellular fluorescence retention with flow cytometry, the activity of $\mathrm{ABC}$ transporters (P-gp and MRP1) under drug treatment in MDR cancer cells can be detected [49-53].

$30,000-50,000$ cells per well were seeded in a 24-well plate, and three concentrations of drugs (plant extracts and $\mathrm{SM})\left(\mathrm{IC}_{50} \times 1, \mathrm{IC}_{50} \times 5, \mathrm{IC}_{50} \times 10\right)$ were added separately to the cells and incubated for $1.5 \mathrm{~h}$ at $37^{\circ} \mathrm{C}$. The cell suspension containing $1 \%$ DMSO without drugs was used as the control group. The P-gp and MRP1 substrate verapamil [54] (50 $\mu \mathrm{M})$ was used as a positive control. After incubation with different compounds, the suspension cells were transferred into $2 \mathrm{~mL}$ Eppendorf tubes and separated from the media by centrifugation. The cells were washed twice with ice-cold PBS. Then $500 \mu \mathrm{L}$ media containing calcein-AM (the final concentration of calcein-AM was $1.25 \mu \mathrm{M}$ for CCRF-CEM and $2.5 \mu \mathrm{M}$ for CEM/ADR 5000 cells) were added to each tube for $1.5 \mathrm{~h}$ incubation at $37^{\circ} \mathrm{C}$. Afterwards, the cells were separated from the media by centrifugation, and washed twice with ice-cold PBS. Then the cells were resuspended in ice-cold PBS and moved to FACS tubes. The cellular fluorescence intensity was measured with FACS at $525 \mathrm{~nm}$.

2.6. ABC Transporter Assay with the Substrate Rhodamine 123 in CCRF-CEM, CEM/ADR 5000 Cells, and Caco-2 Cells

For CCRF-CEM cells, the procedure was the same as that with calcein-AM; only calcein-AM was replaced with $10 \mu \mathrm{M}$ rhodamine 123 (rho 123). For CEM/ADR 5000 cells, 30,000-50,000 cells per well were seeded in a 24-well plate and pre-incubated at $37^{\circ} \mathrm{C}$ for $1 \mathrm{~h}$ in the presence of $10 \mu \mathrm{M}$ rho 123 . Then the suspension cells were transferred into $2 \mathrm{~mL}$ Eppendorf tubes and separated from the media by centrifugation. The cells were washed twice with ice-cold PBS. Then $500 \mu \mathrm{L}$ media containing various concentrations of drugs were added to each tube for $1.5 \mathrm{~h}$ incubation at $37^{\circ} \mathrm{C} .1 \%$ DMSO was used as the control group, and $50 \mu \mathrm{M}$ verapamil was used as a positive control. Afterwards, the cells were separated from the media by centrifugation, and washed twice with ice-cold PBS. Then the cells were resuspended in ice-cold PBS and moved to FACS tubes. The cellular fluorescence intensity was determined by FACS at $525 \mathrm{~nm}$.

For Caco-2, cells were grown in a 96-well plate until a monolayer was formed in each well. Fresh media containing different concentrations of drugs were added to the cells (each treatment was in triplicate). Verapamil was used as a positive control. The cells were incubated at $37^{\circ} \mathrm{C}$ for $5 \mathrm{~h}$. Afterwards, the media were removed and new media containing $10 \mu \mathrm{M}$ rho 123 were added to the cells for $1.5 \mathrm{~h}$ further incubation. Then the media were removed and the cells were washed once with PBS. After addition of $100 \mu \mathrm{L}$ PBS containing $0.1 \%$ Triton to each well the fluorescence was read at $535 \mathrm{~nm}$ with the Tecan Nano Quant infinite F200 PRO Plate Reader (Tecan, Männedorf, Switzerland). 


\subsection{Gene Expression Analysis by by Real-Time PCR}

CEM-ADR 5000 and Caco-2 cells were treated with various single substances for $48 \mathrm{~h}$. Then, RNA were extracted with the RNA purification kit (EURx, Roboklon, Berlin, Germany) following the protocol of the supplier. After the purification, RNA was reverse-transcribed to cDNA with FastGene Scriptase Basic cDNA Kit (NIPPON GENETICS, Dueren, Germany) following the protocols of the supplier. Then real-time PCR were performed with SensiFAST SYBR No-ROX kit (Bioline, Luckenwalde, Germany) or ORA ${ }^{\mathrm{TM}}$ qPCR Green ROX L Mix, 2X (HighQu, Kraichtal, Germany). In each reaction, the following agents were added: $0.1 \mu \mathrm{L}$ DMSO, $0.1 \mu \mathrm{M}$ forward and reverse primers (Table 1), 100-500 ng cDNA template, $5 \mu \mathrm{L}$ SYBR qPCR Mix or Green ROX L Mix, and then add water to $10 \mu \mathrm{L}$ final volume. Each reaction was conducted in triplicate. After centrifuging, the reaction plate was sealed with transparent qPCR folie and placed into Roche LightCycler ${ }^{\circledR} 96$ Real-Time PCR instrument (Roche, Penzberg, Germany). The reaction steps were set like this: 1 cycle of $95^{\circ} \mathrm{C}-2$ min initial denaturation, 40 cycles of $95^{\circ} \mathrm{C}-5 \mathrm{~s}$ denaturation, 40 cycles of $60-65^{\circ} \mathrm{C} 10 \mathrm{~s}$ annealing, 40 cycles of $72{ }^{\circ} \mathrm{C} 20 \mathrm{~s}$ extension, and $4{ }^{\circ} \mathrm{C}$ cooling. The data was analysed using $2^{-\Delta \Delta \mathrm{Ct}}$ following Yuan et al. [55].

Table 1. Primers used in this study for qPCR.

\begin{tabular}{ccc}
\hline Gene & Sequences & Amplicon \\
\hline RPL13 & $\begin{array}{c}\text { Forward: GAGGCGGAACAAGTCCAC } \\
\text { Reverse: AGGATGAGTTTGGAGCGGTA }\end{array}$ & $75 \mathrm{nt}$ \\
\hline ABCB1 & $\begin{array}{c}\text { Forward: TTACATTCAGGTTTCATTTTGGTG } \\
\text { Reverse: TCCTGTCGCATTATAGCATGA }\end{array}$ & $90 \mathrm{nt}$ \\
\hline ABCC1 & $\begin{array}{c}\text { Forward: TTGGGATTTTTGCTGTGGA } \\
\text { Reverse: ATATGCCCCGACTTCTTTCC }\end{array}$ & $73 \mathrm{nt}$ \\
\hline GSTP1 & $\begin{array}{c}\text { Forward: AATGGCAACGGGAAACAGT } \\
\text { Reverse: TTGGTCCTGGAGAAAGGAAG }\end{array}$ & $77 \mathrm{nt}$ \\
\hline CAS 3 & $\begin{array}{c}\text { Forward: TCTCATGCTGCAGAGGGTACT } \\
\text { Reverse: TGGAAGTTTGAGGTAGCTTCATAG }\end{array}$ & $77 \mathrm{nt}$ \\
\hline CAS 8 & $\begin{array}{c}\text { Forward: GGAAAGCAATCTGTCCTTCCT } \\
\text { Reverse: CAGCAAATCCAGTCTATTAATTCG }\end{array}$ & $61 \mathrm{nt}$ \\
\hline AhR & $\begin{array}{c}\text { Forward: AGAGTTGGACCGTTTGGCTA } \\
\text { Reverse: CGCTGAGCCTAAGAACTGAAA }\end{array}$ & $86 \mathrm{nt}$ \\
\hline CYP1A1 & $\begin{array}{c}\text { Forward: CCACCAAGAACTGCTTAGCC } \\
\text { Reverse: CAGCTGGGTTTCCAGAGC }\end{array}$ & $74 \mathrm{nt}$ \\
\hline
\end{tabular}

RPL13 is the reference gene. GSTP1 = GSTpi 1; CAS 3 = caspase 3; CAS $8=$ caspase 8.

\subsection{Reversal Ratio}

The reversal ratio, also referred to as "fold-sensitization," or "MDR ratio" etc., evaluates the reversal effect of a chemosensitizer by comparing the $\mathrm{IC}_{50}$ values of a toxic drug combined with a nontoxic concentration of a chemosensitizer and used alone [54].

Here the reversal ratio is calculated with the following equation:

$$
\text { Reversal ration }=\frac{\mathrm{IC}_{50} \text {, dox alone }}{\mathrm{IC}_{50} \text {, dox in combination }}
$$

It suggests whether the combination of a substance with dox can reverse the resistance of a cell line to dox.

\subsection{Combination Index (CI)}

For the two- and three-drug combination in CEM/ADR 5000 and Caco-2 cells, combination index (CI) was calculated with the following equations according to Zhao et al. [56]. 
For two-drug combinations:

$$
\mathrm{CI}=\frac{\mathrm{C}_{d o x, 50}}{\mathrm{IC}_{50, d o x}}+\frac{\mathrm{C}_{S M}}{\mathrm{IC}_{50, S M}}
$$

For three-drug combinations:

$$
\mathrm{CI}=\frac{\mathrm{C}_{d o x, 50}}{\mathrm{IC}_{50, d o x}}+\frac{\mathrm{C}_{S M}}{\mathrm{IC}_{50, S M}}+\frac{\mathrm{C}_{d i g}}{\mathrm{IC}_{50, d i g}}
$$

$\mathrm{C}_{d o x, 50}$ is the $\mathrm{IC}_{50}$ of dox in combination.

$\mathrm{IC}_{50, d o x}$ is the $\mathrm{IC}_{50}$ of dox alone in a cell line.

$\mathrm{C}_{S M}$ is the constant concentration of a single substance in combination.

$\mathrm{IC}_{50, S M}$ is the $\mathrm{IC}_{50}$ of a single substance (a secondary metabolite or a plant extract) in the cell line.

$\mathrm{C}_{\text {dig }}$ is the concentration of digitonin used in combination. It is $0.5 \mu \mathrm{M}$ in this study.

$\mathrm{IC}_{50, \text { dig }}$ is the $\mathrm{IC}_{50}$ of digitonin in the cell line.

The interpretation of $\mathrm{CI}$ was according to Chou [57]: $\mathrm{CI}<0.1$ very strong synergism $(+++++)$, 0.1-0.3 strong synergism $(++++), 0.3-0.7$ synergism $(+++), 0.7-0.85$ moderate synergism $(++), 0.85-0.9$ slight synergism $(+), 0.9-1.10$ nearly additivity $( \pm), 1.10-1.20$ slight antagonism $(-), 1.20-1.45$ moderate antagonism (--), 1.45-3.3 antagonism (---), 3.3--10 strong antagonism (----), and $>10$ very strong antagonism (----). NR = not relevant.

\subsection{Statistical Analysis}

All the results are expressed as the mean \pm SD from at least three independent experiments. The data were analysed with SigmaPlot ${ }^{\circledR} 11.0$ (Systat Software, San Jose, CA, USA) and GraphPad Prism 6 (Graphpad Software, San Diego, CA, USA). Statistical significance was assessed with $t$-test. When $p<0.05$, the difference was regarded as significant.

\section{Results}

\subsection{Cytotoxicity of Single Substances against Drug Sensitive and Resistant Cells}

The antiproliferative activity of the individual substances in CCRF-CEM, CEM/ADR 5000, HCT-116 and Caco-2 cells was measured using MTT assay (Table 2). CEM/ADR 5000 and Caco-2 cells overexpress $\mathrm{ABC}$ transporters and are therefore less sensitive to doxorubicin than CCRF-CEM or HCT-116, which do not express them. The cytotoxic effect of the plant substances can be considered as moderate. Digitonin and ursolic acid are the most active PSM in our panel and exhibit $\mathrm{IC}_{50}$ values between 0.7 and $20 \mu \mathrm{M}$. The $\mathrm{IC}_{50}$ values of ga and pae were above $400 \mu \mathrm{M}$, indicating that they are not toxic to cells (Table 2).

Table 2. Cytotoxicity $\left(\mathrm{IC}_{50}\right.$ values ${ }^{*}$ ) of individual extracts or secondary metabolites in four kinds of cancer cells.

\begin{tabular}{ccccc}
\hline Sub-stances & CCRF-CEM & CEM/ADR 5000 & Caco-2 & HCT-116 \\
\hline Dox & $0.17 \pm 0.06$ & $93.24 \pm 19.02$ & $5.40 \pm 1.27$ & $0.73 \pm 0.04$ \\
Dig & $10.65 \pm 1.07$ & $13.06 \pm 2.38$ & $11.28 \pm 0.74$ & $0.70 \pm 0.10$ \\
Ge & $96.63 \pm 4.21$ & $148.31 \pm 9.57$ & $352.97 \pm 8.10$ & $305.04 \pm 4.78$ \\
Pe & $56.15 \pm 1.99$ & $85.93 \pm 3.58$ & $134.64 \pm 14.90$ & $202.14 \pm 12.09$ \\
Ue & $50.88 \pm 4.51$ & $58.17 \pm 3.05$ & $98.95 \pm 11.57$ & $67.61 \pm 2.89$ \\
ga & $406.71 \pm 24.77$ & $564.83 \pm 19.06$ & $602.65 \pm 31.39$ & $1415.46 \pm 113.43$ \\
18ga & $76.20 \pm 0.93$ & $81.72 \pm 0.43$ & $126.18 \pm 26.86$ & $113.17 \pm 1.77$ \\
liq & $88.41 \pm 4.86$ & $131.61 \pm 6.82$ & $746.43 \pm 92.93$ & $349.27 \pm 16.83$ \\
iso & $26.09 \pm 0.83$ & $55.98 \pm 1.60$ & $98.79 \pm 11.27$ & $28.26 \pm 0.89$ \\
pae & $802.11 \pm 28.93$ & $1376.96 \pm 195.12$ & $822.27 \pm 297.99$ & $1146.11 \pm 120.48$ \\
urs & $10.28 \pm 0.39$ & $14.47 \pm 0.65$ & $22.37 \pm 1.22$ & $13.10 \pm 0.19$ \\
Ver & - & $130.08 \pm 32.49$ & $35.29 \pm 3.32$ & - \\
\hline
\end{tabular}

* Units for $\mathrm{Ge}, \mathrm{Pe}$, and Ue are $\mu \mathrm{g} / \mathrm{mL}$, others are $\mu \mathrm{M}$. Ge = Glycyrrhiza glabra extract; $\mathrm{Pe}=$ Paeonia lactiflora extract; $\mathrm{Ue}=$ Eriobotrya japonica extract. 


\subsection{Combinations Enhance the Cytotoxicity of Doxorubicin}

A nontoxic dose of a single extract or secondary metabolite was combined with different concentrations of doxorubicin or doxorubicin plus $0.5 \mu \mathrm{M}$ digitonin to test whether the two- and three-drug combinations can restore or even increase the cytotoxicity of doxorubicin and overcome the drug resistance in CEM/ADR 5000 (Table 3) and Caco-2 cells (Table 4). In CEM/ADR 5000 cells, all two- and three-drug combinations lowered the $\mathrm{IC}_{50}$ of doxorubicin, and reversed the resistance of CEM/ADR 5000 to doxorubicin with a reversal ratio $>1$. The combination index $(\mathrm{CI})$ varied and indicated interactions from synergism to antagonism. Three-drug combinations were even more effective than two-drug combinations, namely, digitonin enhanced the reversal effect of all single substances. In Caco-2 cells, all the substances showed a similar effect as in CEM/ADR 5000 cells, except liquiritigenin (liq) and isoliquiritigenin (iso). When doxorubicin was combined with liq or iso alone, the $\mathrm{IC}_{50}$ of doxorubicin was not lowered but increased, the reversal ratio was $<1$, and the $\mathrm{CI}$ indicated antagonism. Only when iso was used in three-drug combination, the $\mathrm{IC}_{50}$ of doxorubicin was somewhat reduced. Importantly, Ue, ga, 18ga, and urs were identified as powerful reversal agents.

Table 3. Cytotoxicity of doxorubicin alone or in combination with a non-toxic concentration of a single substance or with a single substance plus digitonin against CEM/ADR 5000 cells. All data were from at least three independent experiments; they are represented as the mean $\pm \mathrm{SD}$. Ge $\left(80 \mu \mathrm{g} / \mathrm{mL}-\mathrm{IC}_{26}\right)$ : the concentration of $\mathrm{Ge}$ in combination was $80 \mu \mathrm{g} / \mathrm{mL}$ and it can cause $26 \%$ of cell death in CEM/ADR 5000 cells.

\begin{tabular}{|c|c|c|c|c|c|c|c|c|}
\hline \multirow{2}{*}{ Substances } & \multicolumn{4}{|c|}{$\begin{array}{l}\text { Two-Drug Combinations } \\
\text { (PSM + Dox) }\end{array}$} & \multicolumn{4}{|c|}{$\begin{array}{c}\text { Three-Drug Combinations } \\
\text { (PSM + Dox + 0.5 } \mu \text { M Digitonin) }\end{array}$} \\
\hline & $\begin{array}{c}\mathrm{IC}_{50}(\mu \mathrm{M} \text { of } \\
\text { Doxorubicin) }\end{array}$ & $\begin{array}{c}\text { Reversal } \\
\text { Ratio }\end{array}$ & CI & Interpretation & $\begin{array}{l}\mathrm{IC}_{50}(\mu \mathrm{M} \text { of } \\
\text { Dox) }\end{array}$ & $\begin{array}{l}\text { Reversal } \\
\text { Ratio }\end{array}$ & CI & Interpretation \\
\hline Dox alone & $93.24 \pm 19.02$ & 1.00 & NR & NR & $93.24 \pm 19.02$ & 1.00 & NR & NR \\
\hline $\mathrm{Ge}\left(80 \mu \mathrm{g} / \mathrm{mL}-\mathrm{IC}_{26}\right)$ & $31.84 \pm 5.45$ & 2.93 & 0.88 & $+($ slight syn $)$ & $23.54 \pm 10.76$ & 3.96 & 0.83 & $++(\bmod \operatorname{syn})$ \\
\hline $\operatorname{Pe}\left(50 \mu \mathrm{g} / \mathrm{mL}-\mathrm{IC}_{3}\right)$ & $74.02 \pm 9.17$ & 1.26 & 1.37 & $-(\bmod a n t)$ & $59.35 \pm 22.22$ & 1.57 & 1.25 & $-(\bmod a n t)$ \\
\hline $\mathrm{Ue}\left(30 \mu \mathrm{g} / \mathrm{mL}-\mathrm{IC}_{15}\right)$ & $49.93 \pm 13.28$ & 1.87 & 1.06 & \pm (nearly add) & $37.44 \pm 7.89$ & 2.49 & 0.96 & \pm (nearly add) \\
\hline ga $\left(300 \mu \mathrm{M}-\mathrm{IC}_{10}\right)$ & $32.34 \pm 2.55$ & 2.88 & 0.88 & + (slight syn) & $26.08 \pm 2.18$ & 3.76 & 0.85 & $++(\bmod s y n)$ \\
\hline $18 \mathrm{ga}\left(50 \mu \mathrm{M}-\mathrm{IC}_{1}\right)$ & $38.11 \pm 6.91$ & 2.45 & 1.02 & \pm (nearly add) & $26.38 \pm 10.49$ & 3.53 & 0.93 & \pm (nearly add) \\
\hline $\operatorname{liq}\left(40 \mu \mathrm{M}-\mathrm{IC}_{18}\right)$ & $57.50 \pm 8.17$ & 1.62 & 0.92 & \pm (nearly add) & $47.56 \pm 7.46$ & 1.96 & 0.85 & $++(\bmod s y n)$ \\
\hline iso $\left(20 \mu \mathrm{M}-\mathrm{IC}_{12}\right)$ & $31.17 \pm 8.60$ & 2.99 & 0.69 & $+++(\operatorname{syn})$ & $25.21 \pm 6.10$ & 3.70 & 0.66 & +++ (syn) \\
\hline pae $\left(500 \mu \mathrm{M}-\mathrm{IC}_{11}\right)$ & $40.27 \pm 5.13$ & 2.32 & 0.79 & $++(\bmod s y n)$ & $34.17 \pm 9.04$ & 2.73 & 0.76 & $++(\bmod \operatorname{syn})$ \\
\hline urs $\left(6 \mu \mathrm{M}-\mathrm{IC}_{17}\right)$ & $30.13 \pm 10.49$ & 3.10 & 0.74 & $++(\bmod s y n)$ & $25.96 \pm 7.67$ & 3.59 & 0.73 & $++(\bmod s y n)$ \\
\hline
\end{tabular}

NR: not relevant. CI: combination index.

Table 4. Cytotoxicity of doxorubicin alone or in combination with a non-toxic concentration of a single substance or with a single substance plus digitonin against Caco-2 cells. All data were from at least three independent experiments and represented as the mean $\pm \mathrm{SD}$.

\begin{tabular}{|c|c|c|c|c|c|c|c|c|}
\hline \multirow{2}{*}{ Substances } & \multicolumn{4}{|c|}{$\begin{array}{l}\text { Two-Drug Combinations } \\
\text { (PSM + Dox) }\end{array}$} & \multicolumn{4}{|c|}{$\begin{array}{c}\text { Three-Drug Combinations } \\
\text { (PSM + Dox + 0.5 } \mu \text { M Digitonin) }\end{array}$} \\
\hline & $\begin{array}{l}\mathrm{IC}_{50}(\mu \mathrm{M} \text { of } \\
\text { Dox) }\end{array}$ & $\begin{array}{l}\text { Reversal } \\
\text { Ratio }\end{array}$ & CI & Interpretation & $\begin{array}{l}\mathrm{IC}_{50}(\mu \mathrm{M} \text { of } \\
\text { Dox) }\end{array}$ & $\begin{array}{l}\text { Reversal } \\
\text { Ratio }\end{array}$ & CI & Interpretation \\
\hline Dox. alone & $5.40 \pm 1.27$ & 1.00 & NR & NR & $5.40 \pm 1.27$ & 1.00 & NR & NR \\
\hline $\mathrm{Ge}\left(200 \mu \mathrm{g} / \mathrm{mL}-\mathrm{IC}_{5}\right)$ & $3.21 \pm 0.72$ & 1.68 & 1.16 & - (slight ant) & $2.14 \pm 1.08$ & 2.52 & 1.01 & \pm (nearly add) \\
\hline $\operatorname{Pe}\left(25 \mu \mathrm{g} / \mathrm{mL}-\mathrm{IC}_{10}\right)$ & $3.44 \pm 0.97$ & 1.32 & 0.82 & $++(\bmod s y n)$ & $0.42 \pm 0.20$ & 2.52 & 0.31 & +++ (syn) \\
\hline $\mathrm{Ue}\left(40 \mu \mathrm{g} / \mathrm{mL}-\mathrm{IC}_{6}\right)$ & $1.10 \pm 0.08$ & 4.91 & 0.60 & +++ (syn) & $0.52 \pm 0.18$ & 10.38 & 0.53 & $+++($ syn $)$ \\
\hline ga $\left(350 \mu \mathrm{M}-\mathrm{IC}_{10}\right)$ & $1.74 \pm 0.56$ & 3.10 & 0.90 & \pm (nearly add) & $0.68 \pm 0.27$ & 7.94 & 0.75 & $++(\bmod s y n)$ \\
\hline $18 \mathrm{ga}\left(25 \mu \mathrm{M}-\mathrm{IC}_{20}\right)$ & $2.08 \pm 0.97$ & 2.60 & 0.58 & +++ (syn) & $0.96 \pm 0.45$ & 5.63 & 0.42 & $+++($ syn $)$ \\
\hline liq $\left(200 \mu \mathrm{M}-\mathrm{IC}_{20}\right)$ & $11.45 \pm 3.78$ & 0.47 & 2.39 & - (ant) & $7.83 \pm 3.65$ & 0.69 & 1.76 & - (ant) \\
\hline iso $\left(30 \mu \mathrm{M}-\mathrm{IC}_{23}\right)$ & $6.36 \pm 1.78$ & 0.85 & 1.48 & - (ant) & $4.61 \pm 1.29$ & 1.17 & 1.20 & $-(\bmod a n t)$ \\
\hline pae $\left(200 \mu \mathrm{M}-\mathrm{IC}_{27}\right)$ & $3.59 \pm 0.79$ & 1.50 & 0.90 & \pm (nearly add) & $3.02 \pm 0.89$ & 1.79 & 0.84 & $++(\bmod s y n)$ \\
\hline urs $\left(8 \mu \mathrm{M}-\mathrm{IC}_{12}\right)$ & $1.45 \pm 0.55$ & 3.72 & 0.63 & +++ (syn) & $0.32 \pm 0.07$ & 16.88 & 0.46 & $+++($ syn) \\
\hline
\end{tabular}

NR: not relevant. CI: combination index.

\subsection{Activity towards ABC Transporters in CEM/ADR 5000 Cells}

In a next set of experiments, we explored if the synergism observed in Tables 3 and 4 might be explained by an inhibition of ABC transporters. Figure 2 shows the cellular calcein AM (Figure 2a) and rhodamine 123 (rho 123) (Figure 2b) retention in CEM/ADR 5000 cells after incubation with the 
test substances. $50 \mu \mathrm{M}$ verapamil (ver) was used as a positive control. In calcein AM assay, high concentrations of $\mathrm{Ge}, \mathrm{Ue}$, ga, iso and pae promoted calcein retention, whereas Pe, Ue, 18ga, liq, and urs had no effect (Figure 2a). In rho 123 assay, Ge, Ue, ga, 18ga, liq, iso, and urs showed a dose-dependent rho 123 retention, although the effect was weaker than that of verapamil. We conclude, that some of our PSM do interfere with p-gp activity.

In the sensitive CCRF-CEM cells, no ABC transporter-mediated drug efflux occurred, the fluorescence of calcein and rhodamine 123 in the control group, positive control verapamil group and drug treatment groups exhibited few or almost no differences, as shown in Figure $3 a, b$.
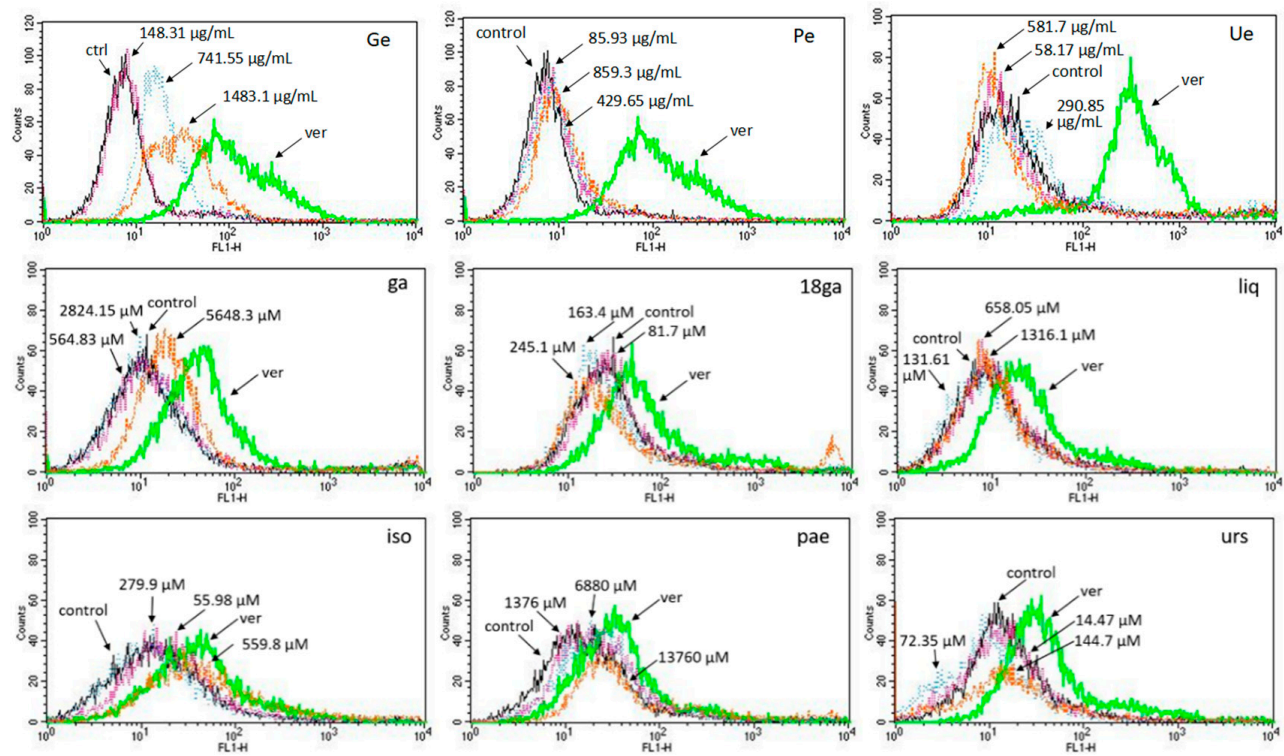

(a)
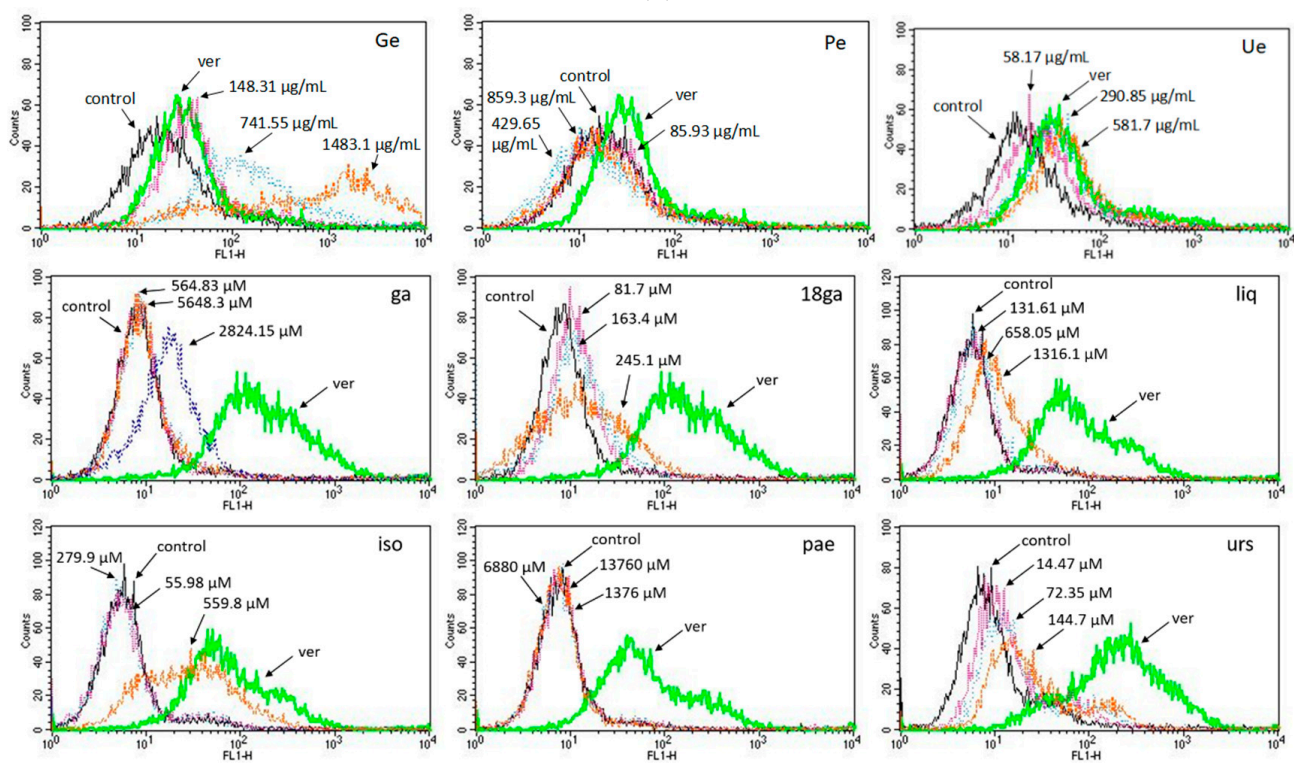

(b)

Figure 2. Histograms of flow cytometry of calcein-AM (a) and rhodamine 123 (b) retention in CEM/ADR 5000 cells after $1.5 \mathrm{~h}$ treatment with three concentrations $\left(\mathrm{IC}_{50}, \mathrm{IC}_{50} \times 5\right.$, and $\left.\mathrm{IC}_{50} \times 10\right)$ of a single substance compared to the treatment with $50 \mu \mathrm{M}$ verapamil (positive control). All experiments were repeated at least three times. 

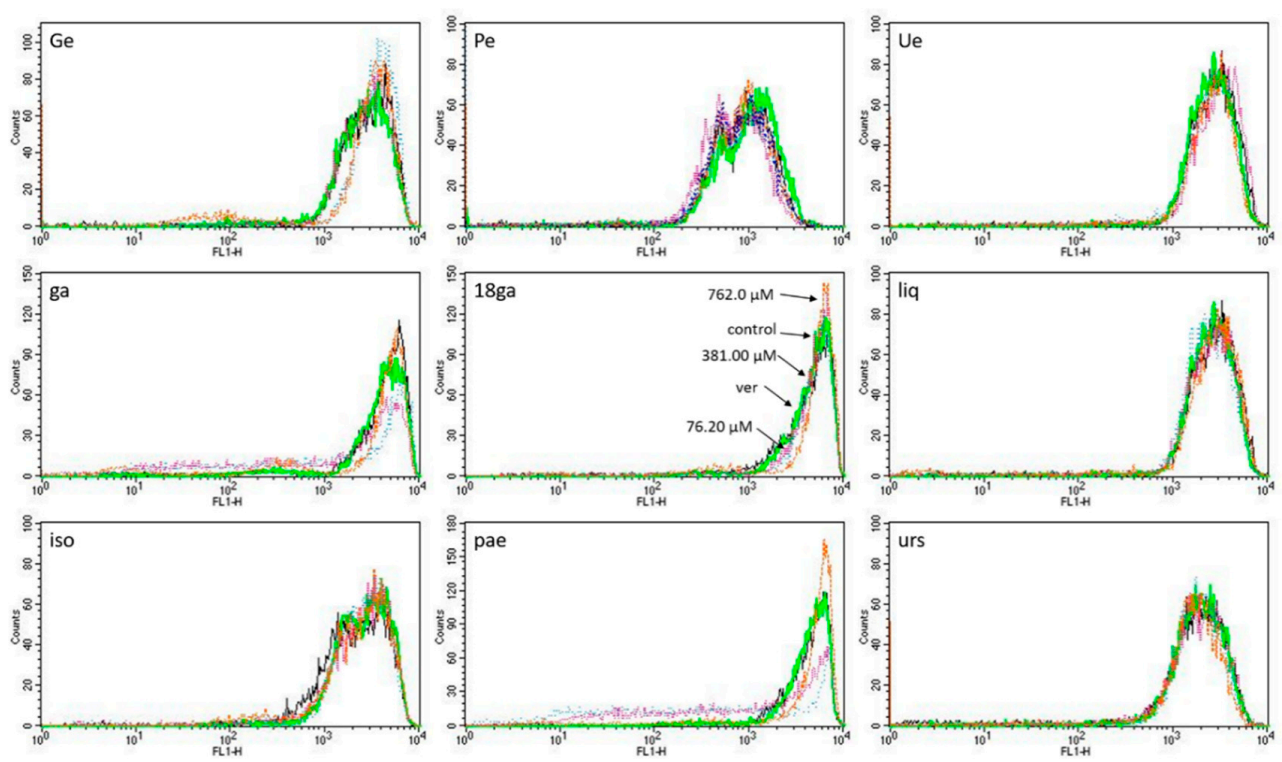

(a)
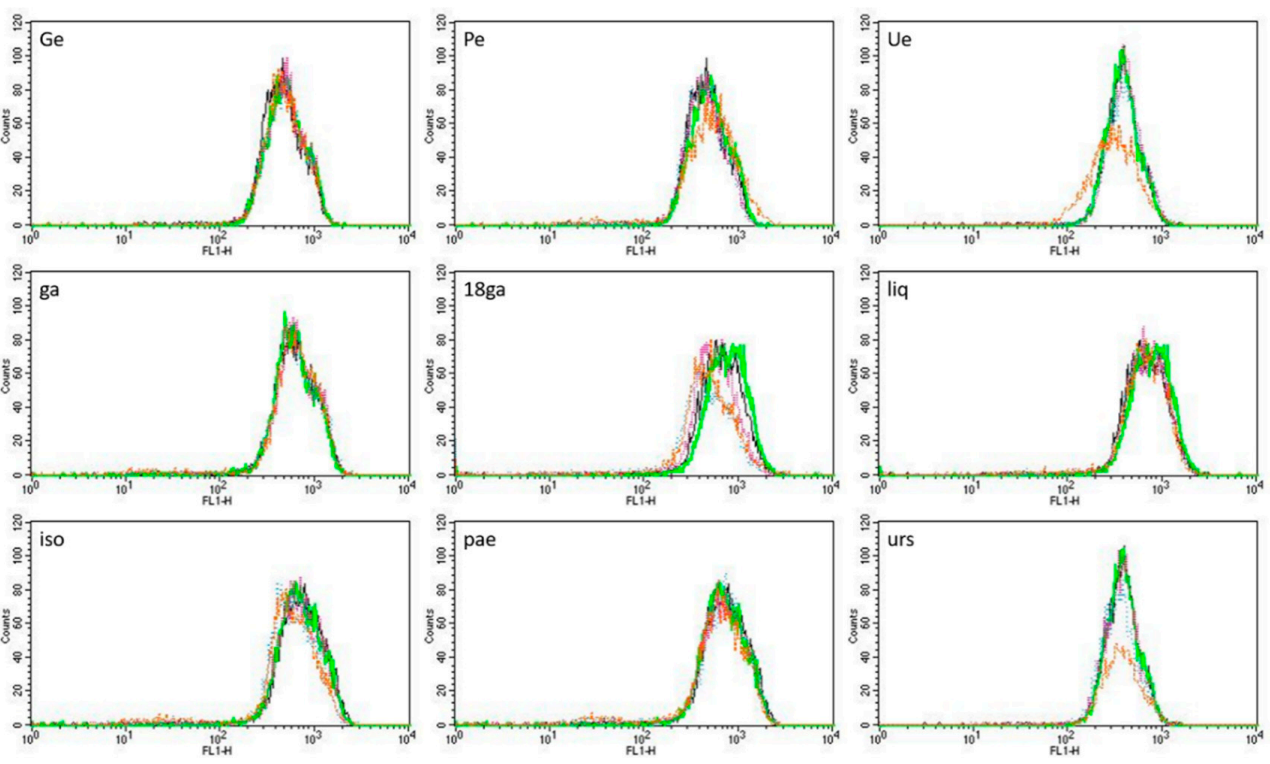

(b)

Figure 3. Histograms of flow cytometry of calcein-AM (a) and rhodamine 123 (b) retention in CCRF-CEM cells after treatment with three concentrations $\left(\mathrm{IC}_{50}, \mathrm{IC}_{50} \times 5\right.$, and $\left.\mathrm{IC}_{50} \times 10\right)$ of single substance compared to the treatment with $50 \mu \mathrm{M}$ verapamil (positive control).

\subsection{Rhodamine 123 Retention in Caco-2 Cells}

In analogy to the experiments with CEM/ADR 5000 cells, Caco-2 cells were treated with our set of single substances for $5 \mathrm{~h}$, and then incubated with rho 123 for $1.5 \mathrm{~h}$ to determine the activity of p-gp. The cellular fluorescence intensity was recorded by spectrometry. As shown in Figure 4, the positive control verapamil, and all the substances except liq demonstrated a dose-dependent trend of rho 123 retention; the higher the concentration, the stronger the cellular fluorescence. Some substances such as ga, 18ga, iso, and pae retained no fluorescence at low concentrations and very weak fluorescence (below 15\%) at higher concentrations. Thus, our panel of PSM does interfere with p-gp to some degree. For liq, all the values were minus zero, suggesting no fluorescence retention, which might correspond to the antagonism of liq in the combinations against Caco-2 cells. 
Ver

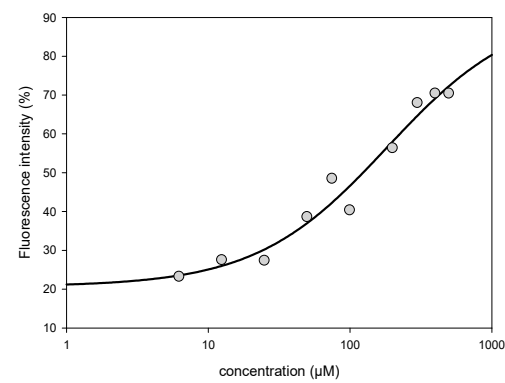

$\mathrm{Pe}$

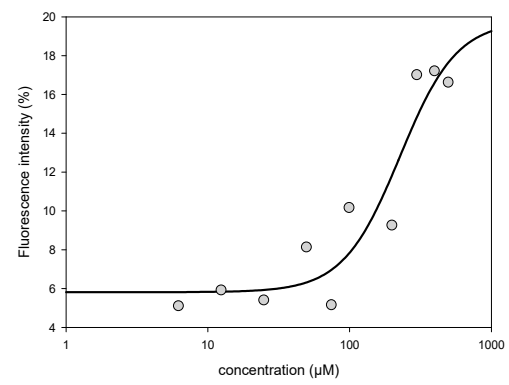

ga

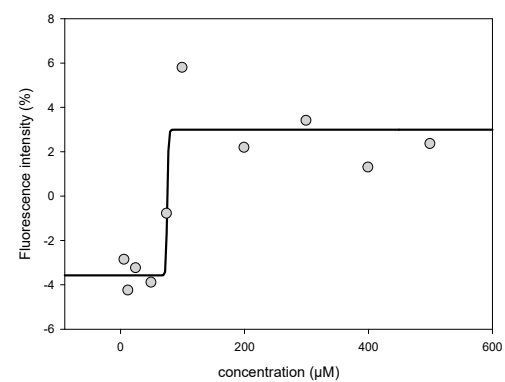

liq

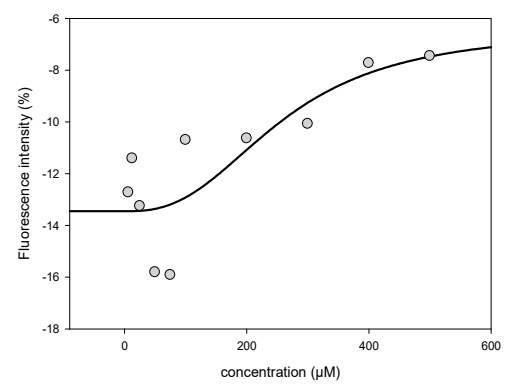

pae

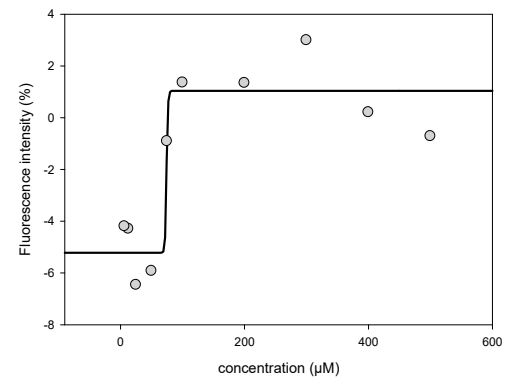

Ge

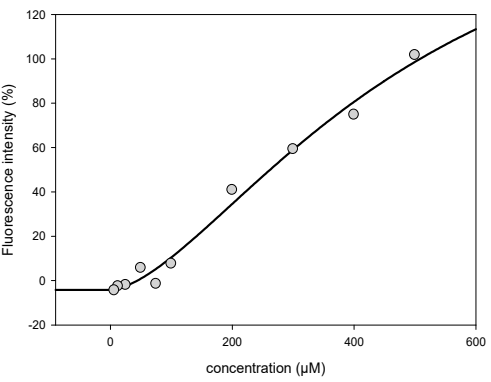

Ue

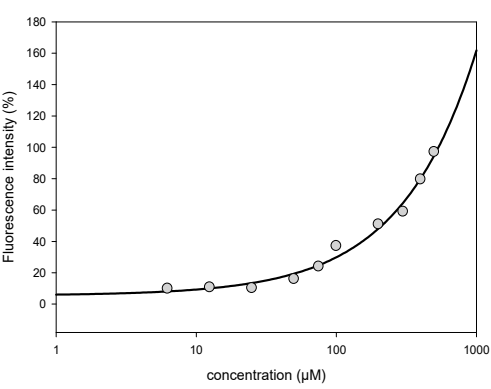

18ga

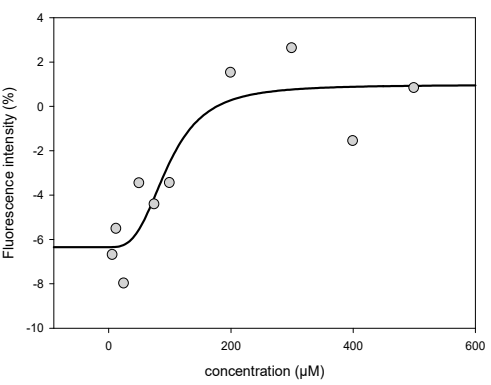

iso
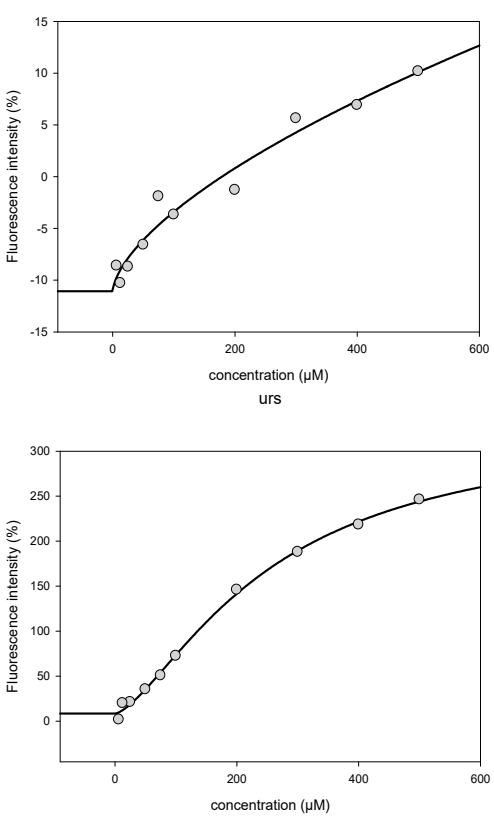

Figure 4. Fluorescence intensity of rhodamine 123 in Caco-2 cells after $5 \mathrm{~h}$ treatment with a single substance. Verapamil was used as a positive control. All data were from at least three experiments represented as the mean $\pm \mathrm{SD}$. 


\subsection{Influence on Gene Expression of MDR Related Genes}

In a last set of experiments, we investigated the role of our PSM panel on the expression of genes related to the MDR phenotype. Concentrations corresponded to non-toxic doses, as used in Tables 2 and 3.

CEM/ADR 5000 cells and Caco-2 cells were treated with our set of single substances for $48 \mathrm{~h}$, and gene expression of ABCB1 (P-gp), ABCC1 (MRP1), caspase 3 (CAS 3), caspase 8 (CAS 8), glutathione S-transferase pi 1 (GSTP1), AhR, and CYP1A1 were analysed by real-time PCR. Figure 5a shows the expression changes of the candidate genes in CEM/ADR 5000 cells, and Figure $5 \mathrm{~b}$ in Caco-2 cells.

In CEM/ADR 5000 cells (Figure 5a), Ue, ga, and 18ga reduced ABCB1 expression, whereas the other PSM induced the transporter gene. Ge, Ue, iso, pae, and urs reduced the ABCC1 expression, whereas the other PSM induced its expression. All the substances upregulated the expression of CAS 3 and CAS 8 to some degree. Except for Ga and pae, all PSM activated GSTP1 expression.

ABCB1

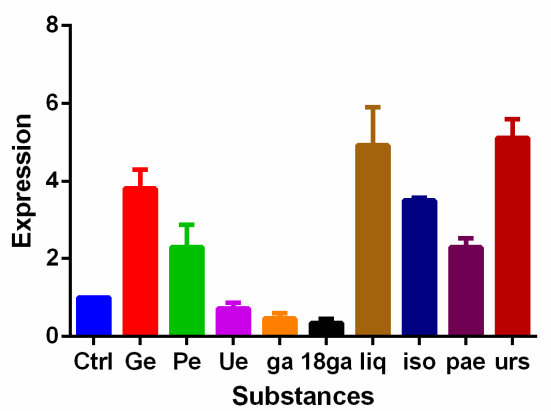

CAS 8

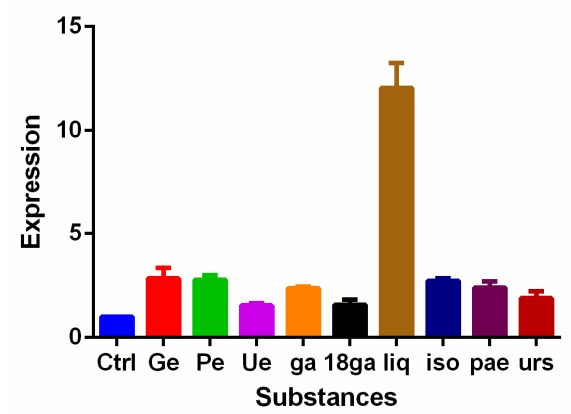

ABCC1

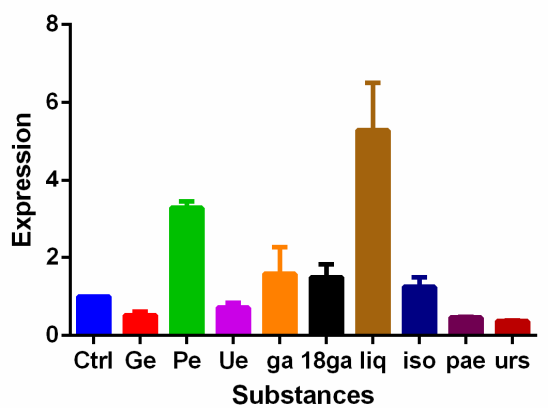

CAS 3

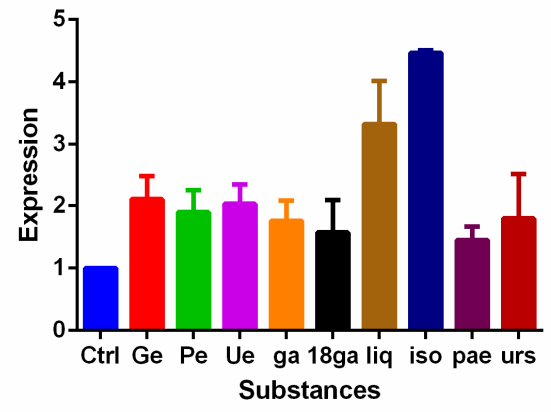

GSTP1

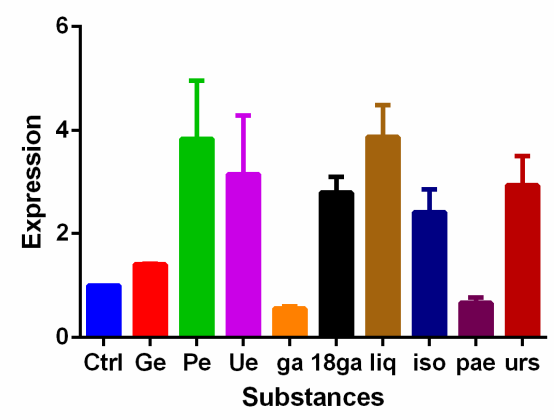

(a)

Figure 5. Cont. 
ABCB1

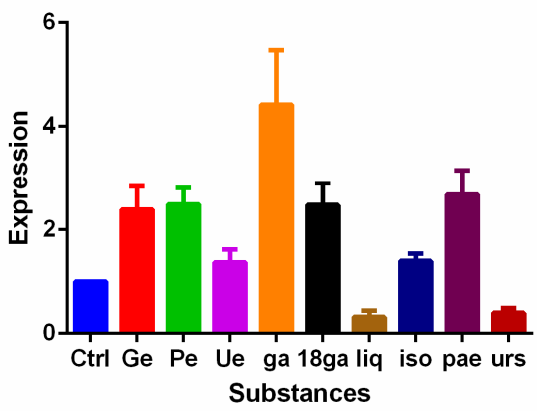

CAS 3

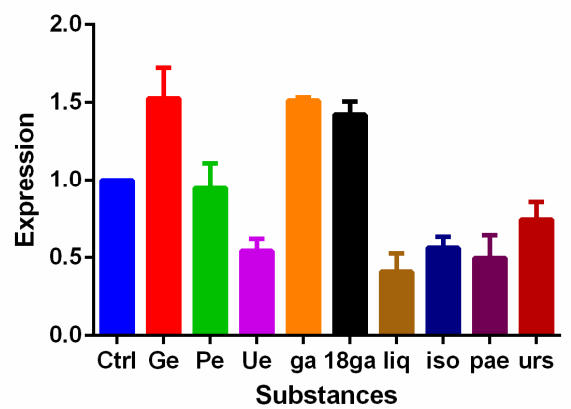

AhR

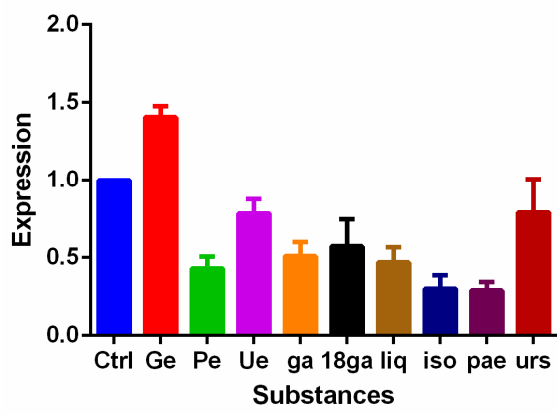

ABCC1

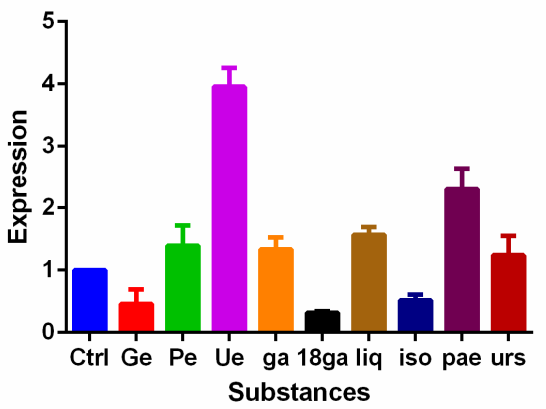

CAS 8

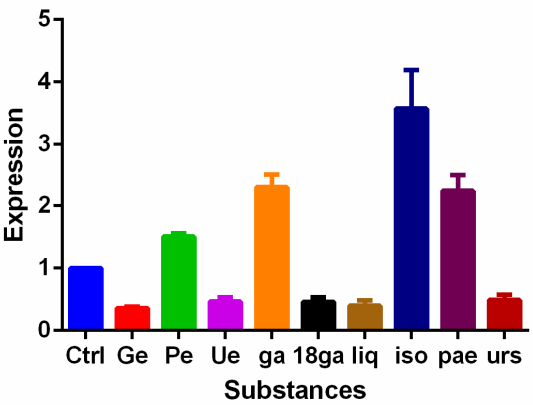

CYP1A1

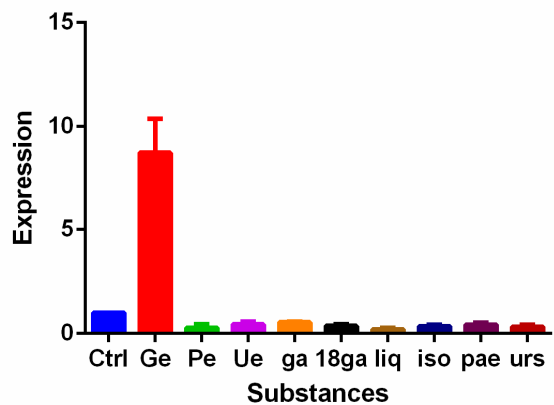

GSTP1

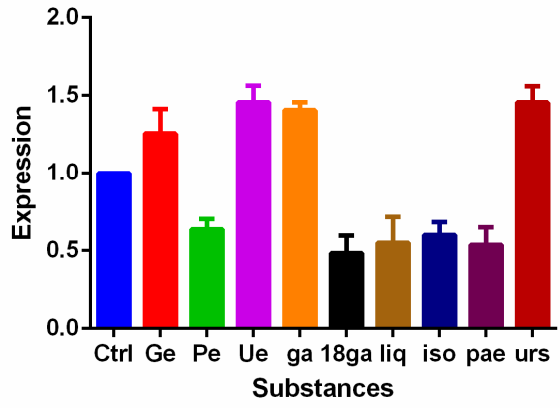

(b)

Figure 5. Effects of non-toxic doses of plant secondary metabolite (PSM) on the expression of various genes after $48 \mathrm{~h}$ treatment compared to the control (no treatment) in CEM/ADR 5000 cells (a) and Caco- 2 cells (b). Concentrations were the same as used in Table 2 (CEM/ADR 5000 cells) and Table 3 (Caco-2 cells). The results are expressed as the mean \pm SD represented at least three independent experiments. The non-treated control group was defined as 1.00 . 
In Caco-2 cells (Figure 5b), liq and urs reduced the ABCB1 expression, Ge, 18ga, and iso reduced ABCC 1 expression. Ga increased both CAS 3 and CAS 8 expressions, iso and pae stimulated CAS 8 expression. Except for $\mathrm{Ge}$, all the other substances down-regulated AhR and CYP1A1 expression levels. At the same time, Pe, 18ga, ga, iso, and pae reduced the GSTP1 expression whereas the other PSM enhanced it.

\section{Discussion}

The three plant extracts, the root extracts of Glycyrrhiza glabra, Paeonia lactiflora, and the leaf extract of Eriobotrya japonica possess moderate cytotoxic properties which agrees with published data $[27,38,58-60]$. So do the six PSM [30,31,34-40,44,46,47], which are major PSM in these TCM plants (Table 2). Only ursolic acid showed $\mathrm{IC}_{50}$ values below $20 \mu \mathrm{M}$. However, the expression of apoptotic marker genes (CAS 3 and CAS 8) was stimulated by the panel, especially in CEM/ADR 5000 cells (Figure 5), which may contribute to the MDR reversal effect seen in two- and three-drug combinations (Tables 3 and 4).

In this study, all substances showed a chemosensitizing effect for doxorubicin in CEM/ADR 5000 cells and in Caco-2 cells, except for liquiritigenin and isoliquiritigenin in Caco-2 cells. Digitonin further enhanced the effect (Tables 3 and 4), which might be through the mechanisms explained by Eid et al. [60]. Namely, digitonin may increase the membrane fluidity, increase drug uptake, reduce $\mathrm{ABC}$ transporter-mediated drug efflux and induce apoptosis. High reversal ratios were observed for Ue, ga, 18ga, and urs in three-drug combinations in Caco-2 cells (Table 4). Most two- and three-drug combinations produced a synergistic effect (Tables 3 and 4).

Our hypothesis was that the panel of PSM might interfere with ABC transporters in MDR cancer cells, which overexpress P-gp. In CEM/ADR 5000 cells, most PSM increased calcein or rhodamine 123 retention in a dose-dependent manner to some degree, but none was more active than the positive control verapamil. Furthermore, relatively high concentrations were required to see an effect (Figure 2). As expected, the panel had no effects in sensitive cancer cells, which do not express P-gp (Figure 3). In Caco-2 cells, also relatively high concentrations were required to inhibit P-gp activity (Figure 4). Nevertheless, the data suggest that the PSM might act as inhibitors of ABC transporters. In case of extracts with polyphenols or phenolic PSM, a non-specific inhibition might be due to binding of polyphenols to the transporter proteins by forming hydrogen and ionic bonds [23,61]. However, most PSM of the panel stimulated the expression of ABCB1 or ABCC1 genes (Figure 5), which would also influence drug retention and counteract the inhibitory effects seen in Figures 2 and 4 . This effect was not mediated via AhR gene expression (Figure $5 b$ ).

The synergistic effects of the PSM panel (Tables 2 and 3) could also be modulated through influence on metabolic enzymes, such as GST and CYP1A1. Only Ge stimulated the expression of CYP1A1 gene (Figure 5b), where the other compounds reduced its activity. For GSTP1 gene expression, the picture is more complicated. In CEM/ADR 5000 cells, Pe, Ue, 18ga, liq, iso, and urs stimulated the expression of the GSTP1 gene, whereas in Caco- 2 cells $\mathrm{Ge}, \mathrm{Ue}$, ga, and urs activated this gene, but $\mathrm{Pe}$, 18ga, liq, iso, and pae reduced its expression (Figure 5). We should not forget that CEM/ADR 5000 cells are leukemia cells and Caco-2 colon cells, which might explain the different responses. Furthermore, only non-toxic doses of PSM were applied; higher doses might have caused stronger effects.

Previous studies reported that $18 \beta$ glycyrrhetinic acid (18ga) inhibited P-gp and MRP1 activity in human MDR cells KB-C2 and KB/MRP [31], showed synergistic effect when combined with doxorubicin or mitomycin in SiHa cells [35], and inhibited P-gp, CYP3A4/5, and depleted glutathione in Caco-2 cells [34]. In our study, 18ga did not inhibit ABC transporters so strongly as the positive control verapamil in both resistant cell lines and only showed synergism in combination with doxorubicin in Caco-2 cells, which might be related to decreased ABCC1, increased Caspase 3, and decreased AhR, CYP1A1, and GSTP1 expressions.

Liquiritigenin and isoliquiritigenin are important components responsible for cytochrome P450 and liquorice interaction [62]. Isoliquiritigenin could chemosensitise human MDR uterine sarcoma cells 
MES-SA//Dx5-R to doxorubicin by promoting apoptosis and autophagy [38]. In this study, liq was apparently not a relevant MDR modulator in both resistant cell lines (Tables 3 and 4). Iso chemosensitised MDR cells to doxorubicin partly might through inhibition of $A B C$ transporters, but showed synergism with doxorubicin in CEM/ADR 5000 cells and antagonism in Caco-2 cells (Tables 3 and 4).

Paeoniflorin modulated MDR against vincristine in human gastric cancer cells SGC7901 partly through inhibition of MDR1, BCL-XL, and BCL-2 expressions [44]. Lipophilic monoterpenes are supposed to target the biomembrane [63]. In our study, paeoniflorin synergistically sensitised CEM/ADR5000 to doxorubicin partly through inhibiting ABC transporters, decreasing ABCC1, increasing caspase expression, and decreasing GSTP1 expressions. Pae did not inhibit ABC transporters in Caco-2 cells and showed additivity in combination, which might be mediated through increasing caspase 8 and reducing AhR, CYP1A1, and GSTP1 expressions.

Ursolic acid (urs) circumvented MDR in human hepatoma cell line R-HepG2 through apoptosis induction but not through P-gp inhibition [46]; ursolic acid increased rhodamine 123 retention in a concentration-dependent manner via inhibiting P-gp in KB-C2 cells [47]. Here, ursolic acid synergistically sensitised both CEM/ADR5000 and Caco-2 cells to doxorubicin by inhibiting ABC transporter activity and expression and interfering with apoptosis- and metabolism-related enzyme expressions. Ursolic acid could be considered as a promising MDR modulator candidate as it showed the highest reversal ratio of our PSM panel in Caco-2 cells.

Natural products can interact in manifold ways with biomembranes, proteins, DNA, RNA, and related enzymes in cells [23,63]. Thus, multitarget effects should be expected when PSM are applied. Our study focused on $\mathrm{ABC}$ transporter functions, and gene expressions of $\mathrm{ABC}$ transporters, apoptosis and metabolism related enzymes, to illustrate the influence of the three plant extracts and their six SM on MDR. Considering our gene expression data, some results are plausible and would support the MDR reversal activity seen in Tables 3 and 4. Other results appear contradictory, which may be due to interaction of the PSM in the panel to targets, which were not studied here and the different types of cancer cells employed. To confirm the observed apoptotic activity, further apoptosis experiments need to be conducted, further studies are required to elucidate the exact mechanisms of these substances in MDR and to find out if they are useful in a clinical context.

\section{Conclusions}

In conclusion, extracts of Glycyrrhiza glabra, Paeonia lactiflora (mixed with Paeonia veitchii), and Eriobotrya japonica, and their PSM, glycyrrhizic acid, $18 \beta$ glycyrrhetinic acid, liquiritigenin, isoliquiritigenin, paeoniflorin, and ursolic acid could sensitise MDR cancer cells to doxorubicin in CEM/ADR 5000, and in Caco-2 cells in two- and three-drug combinations. Ue, ga, 18ga, and urs were identified as potential MDR modulator candidates. However, more studies are required to corroborate the findings.

Author Contributions: Conceptualization, J.-X.Z. and M.W.; writing—original draft preparation, J.-X.Z.; review and editing, M.W.; supervision, M.W.

Funding: We acknowledge financial support by Deutsche Forschungsgemeinschaft within the funding programme Open Access Publishing, by the Baden-Württemberg Ministry of Science, Research and the Arts and by Ruprecht-Karls-Universität Heidelberg.

Conflicts of Interest: The authors declare no conflict of interest.

\section{References}

1. Ambudkar, S.V.; Dey, S.; Hrycyna, C.A.; Ramachandra, M.; Pastan, I.; Gottesman, M. Biochemical, cellular, and pharmacological aspects of the multidrug transporter. Annu. Rev. Pharmacol. Toxicol. 1999, 39, 361-398. [CrossRef] [PubMed]

2. Baguley, B.C. Multiple drug resistance mechanisms in cancer. Mol. Biotechnol. 2010, 46, 308-316. [CrossRef] [PubMed] 
3. Szakács, G.; Paterson, J.K.; Ludwig, J.A.; Booth-Genthe, C.; Gottesman, M.M. Targeting multidrug resistance in cancer. Nat. Rev. Drug Discov. 2006, 5, 219-234. [CrossRef] [PubMed]

4. Stavrovskaya, A.A.; Rybalkina, E.Y. Recent advances in the studies of molecular mechanisms regulating multidrug resistance in cancer cells. Biochemistry 2018, 83, 779-786. [CrossRef] [PubMed]

5. Zhitomirsky, B.; Assaraf, Y.G. Lysosomes as mediators of drug resistance in cancer. Drug Resist. Updates 2016, 24, 23-33. [CrossRef] [PubMed]

6. Tan, B.; Piwnica-Worms, D.; Ratner, L. Multidrug resistance transporters and modulation. Curr. Opin. Oncol. 2000, 12, 450-458. [CrossRef] [PubMed]

7. Juliano, R.L.; Ling, V. A surface glycoprotein modulating drug in Chinese hamster ovary cell mutants. Biochim. Biophys. Acta 1976, 455, 152-162. [CrossRef]

8. Cole, S.P.C.; Bhardwaj, G.; Gerlach, J.H.; Mackie, J.E.; Grant, C.E.; Almquist, K.C.; Stewart, A.J.; Kurz, E.U.; Duncan, A.M.V.; Deeley, R.G. Overexpression of a transporter gene in a multidrug-resistant human lung cancer cell line. Science 1992, 258, 1650-1654. [CrossRef] [PubMed]

9. Bakos, É.; Hegedüs, T.; Holló, Z.; Welker, E.; Tusnády, G.E.; Zaman, G.J.R.; Flens, M.J.; Váradi, A.; Sarkadi, B. Membrane topology and glycosylation of the human multidrug resistance-associated protein. J. Biol. Chem. 1996, 271, 12322-12326. [CrossRef] [PubMed]

10. Hanahan, D.; Weinberg, R.A. The hallmarks of cancer. Cell 2000, 100, 57-70. [CrossRef]

11. Hanahan, D.; Weinberg, R.A. Hallmarks of cancer: The next generation. Cell 2011, 144, 646-674. [CrossRef] [PubMed]

12. Thornberry, N.A.; Lazebnik, Y. Caspases: Enemies within. Science 1998, 281, 1312-1316. [CrossRef] [PubMed]

13. Tsay, J.J.; Tchou-Wong, K.M.; Greenberg, A.K.; Pass, H.; Rom, W.N. Aryl hydrocarbon receptor and lung cancer. Anticancer Res. 2013, 33, 1247-1256. [PubMed]

14. Hao, N.; Whitelaw, M.L. The emerging roles of AhR in physiology and immunity. Biochem. Pharmacol. 2013, 86, 561-570. [CrossRef] [PubMed]

15. Rodriguez-Antona, C.; Ingelman-Sundberg, M. Cytochrome P450 pharmacogenetics and cancer. Oncogene 2006, 25, 1679-1691. [CrossRef] [PubMed]

16. Su, F.; Hu, X.; Jia, W.; Gong, C.; Song, E.; Hamar, P. Glutathion S transferase Pi indicates chemotherapy resistance in breast cancer. J. Surg. Res. 2003, 113, 102-108. [CrossRef]

17. Duvoix, A.; Schmitz, M.; Schnekenburger, M.; Dicato, M.; Morceau, F.; Galteau, M.-M.; Diederich, M. Transcriptional regulation of glutathione S-transferase Pi-1 in human leukemia. BioFactors 2003, 17, 131-138. [CrossRef] [PubMed]

18. Tacar, O.; Sriamornsak, P.; Dass, C.R. Doxorubicin: An update on anticancer molecular action, toxicity and novel drug delivery systems. J. Pharm. Pharmacol. 2013, 65, 157-170. [CrossRef] [PubMed]

19. Alberts, D.S.; Colvin, O.M.; Conney, A.H.; Ernster, V.L.; Garber, J.E.; Greenwald, P.; Gudas, L.J.; Waun, K.H.; Kelloff, G.J.; Kramer, R.A.; et al. Prevention of cancer in the next millennium: Report of the chemoprevention working group to the American association for cancer research. Cancer Res. 1999, 59, 4743-4758.

20. Fiskum, G. Intracellular levels and distribution of $\mathrm{Ca}^{2+}$ in digitonin permeabilized cells. Cell Calcium 1985, 6, 25-37. [CrossRef]

21. Wink, M.; Ashour, M.L.; El-Readi, M.Z. Secondary metabolites from plants inhibiting ABC transporters and reversing resistance of cancer cells and microbes to cytotoxic and antimicrobial agents. Front. Microbiol. 2012, 3. [CrossRef] [PubMed]

22. Fiore, C.; Eisenhut, M.; Ragazzi, E.; Zanchin, G.; Armanini, D. A history of the therapeutic use of liquorice in Europe. J. Ethnopharmacol. 2005, 99, 317-324. [CrossRef] [PubMed]

23. Van Wyk, B.E.; Wink, M. Medicinal Plants of the World, 2nd ed.; CABI: Wallingford, UK, 2017.

24. Asl, M.N.; Hosseinzadeh, H. Review of pharmacological effects of Glycyrrhiza sp. and its bioactive compounds. Phytother. Res. 2008, 22, 709-724. [CrossRef] [PubMed]

25. Kuang, Y.; Li, B.; Fan, J.; Qiao, X.; Ye, M. Antitussive and expectorant activities of licorice and its major compounds. Bioorg. Med. Chem. 2017, 26, 278-284. [CrossRef] [PubMed]

26. Zhang, W.; Dai, S. Mechanisms involved in the therapeutic effects of Paeonia lactiflora Pallas in rheumatoid arthritis. Int. Immunopharmacol. 2012, 14, 27-31. [CrossRef] [PubMed]

27. European Medicine Agency. Assessment Report on Paeonia lactiflora Pallas, Radix (Paeoniae Radix Alba). Available online: https:/ / www.ema.europa.eu/documents/herbal-report/draft-assessment-reportpaeonia-lactiflora-pallas-radix-paeoniae-radix-alba_en.pdf (accessed on 31 January 2017). 
28. Guo, J.; Pang, J.; Wang, X.; Shen, Z.; Jin, M.; Li, J. In vitro screening of traditionally used medicinal plants in China against enteroviruses. World J. Gastroenterol. 2006, 12, 4078-4081. [CrossRef] [PubMed]

29. Chen, J.; Li, W.; Wu, J.; Ren, B.; Zhang, H. Euscaphic acid, a new hypoglycemic natural product from Folium Eriobotryae. Pharmazie 2008, 63, 765-767. [PubMed]

30. Su, X.; Wu, L.; Hu, M.; Dong, W.; Xu, M.; Zhang, P. Glycyrrhizic acid: A promising carrier material for anticancer therapy. Biomed. Pharmacother. 2017, 95, 670-678. [CrossRef] [PubMed]

31. Nabekura, T.; Yamaki, T.; Ueno, K.; Kitagawa, S. Inhibition of P-glycoprotein and multidrug resistance protein 1 by dietary phytochemicals. Cancer Chemother. Pharmacol. 2008, 62, 867-873. [CrossRef] [PubMed]

32. Yu, J.; Ha, J.Y.; Kim, K.; Jung, Y.; Jung, J.; Oh, S. Anti-inflammatory activities of licorice extract and its active compounds, glycyrrhizic acid, liquiritin and liquiritigenin, in BV2 cells and mice liver. Molecules 2015, 20, 13041-13054. [CrossRef] [PubMed]

33. Kalani, K.; Agarwal, J.; Alam, S.; Khan, F.; Pal, A.; Srivastava, S.K. In silico and in vivo anti-malarial studies of $18 \beta$ glycyrrhetinic acid acid from Glycyrrhiza glabra. PLoS ONE 2013, 8, e74761. [CrossRef] [PubMed]

34. Li, X.; Hu, J.; Wang, B.; Sheng, L.; Liu, Z.; Yang, S.; Li, Y. Inhibitory effects of herbal constituents on P-glycoprotein in vitro and in vivo: Herb-drug interactions mediated via P-gp. Toxicol. Appl. Pharmacol. 2014, 275, 163-175. [CrossRef] [PubMed]

35. Lee, C.S.; Kim, Y.J.; Lee, M.S.; Han, E.S.; Lee, S.J. $18 \beta$ glycyrrhetinic acid induces apoptotic cell death in SiHa cells and exhibits a synergistic effect against antibiotic anti-cancer drug toxicity. Life Sci. 2008, 83, 481-489. [CrossRef] [PubMed]

36. Wang, D.; Wong, H.; Feng, Y.; Zhang, Z. Liquiritigenin exhibits antitumour action in pituitary adenoma cells via Ras/ERKs and ROS-dependent mitochondrial signalling pathways. J. Pharm. Pharmacol. 2013, 66, 408-417. [CrossRef] [PubMed]

37. Yang, E.; Park, G.H.; Song, K. Neuroprotective effects of liquiritigenin isolated from licorice roots on glutamate-induced apoptosis in hippocampal neuronal cells. Neurotoxicology 2013, 39, 114-123. [CrossRef] [PubMed]

38. Lin, L.; Wu, C.; Shieh, T.; Chen, H.; Huang, T.; Hsia, S. The liquorice dietary component isoliquiritigenin chemosensitizes human uterine sarcoma cells to doxorubicin and inhibits cell growth by inducing apoptosis and autophagy via inhibition of m-TOR signaling. J. Funct. Foods 2017, 33, 332-344. [CrossRef]

39. Li, Y.; Zhao, H.; Wang, Y.; Zheng, H.; Yu, W.; Chai, H.; Zhang, J.; Falck, J.R.; Guo, A.M.; Yue, J.; et al. Isoliquiritigenin induces growth inhibition and apoptosis through downregulating arachidonic acid metabolic network and the deactivation of PI3K/Akt in human breast cancer. Toxicol. Appl. Pharmacol. 2013, 272, 37-48. [CrossRef] [PubMed]

40. Hsu, Y.; Kuo, P.; Lin, L.; Lin, C. Isoliquiritigenin inhibits cell proliferation and induces apoptosis in human hepatoma cells. Planta Med. 2005, 71, 130-134. [CrossRef] [PubMed]

41. Jiang, W.; Chen, X.; Zhu, H.; Gao, Y.; Tian, J.; Fu, F. Paeoniflorin inhibits systemic inflammation and improves survival in experimental sepsis. Basic Clin. Pharmacol. Toxicol. 2009, 105, 64-71. [CrossRef] [PubMed]

42. Zhang, T.; Yang, Z.; Yang, S.; Du, J.; Wang, S. Immunoregulatory effects of paeoniflorin exerts anti-asthmatic effects via modulation of the Th1/Th2 equilibrium. Inflammation 2015, 38, 2017-2025. [CrossRef] [PubMed]

43. Zhong, M.; Song, W.; Xu, Y.; Ye, Y.; Feng, L. Paeoniflorin ameliorates ischemic neuronal damage in vitro via adenosine A1 receptor-mediated transactivation of epidermal growth factor receptor. Acta Pharmacol. Sin. 2015, 36, 298-310. [CrossRef] [PubMed]

44. Fang, S.; Zhu, W.; Zhang, Y.; Shu, Y.; Liu, P. Paeoniflorin modulates multidrug resistance of a human gastric cancer cell line via the inhibition of NF-кB activation. Mol. Med. Rep. 2012, 5, 351-356. [PubMed]

45. Jäger, S.; Trojan, H.; Kopp, T.; Laszczyk, M.N.; Scheffler, A. Pentacyclic triterpene distribution in various plants-Rich sources for a new group of multi-potent plant extracts. Molecules 2009, 14, 2016-2031. [CrossRef] [PubMed]

46. Zhang, D.; Tang, P.M.; Chan, J.Y.; Lam, H.; Au, S.W.; Kong, S.; Tsui, S.K.; Waye, M.M.; Mak, T.C.; Fung, K. Anti-proliferative effect of ursolic acid on multidrug resistant hepatoma cells R-HepG2 by apoptosis induction. Cancer Biol. Ther. 2007, 6, 1377-1385. [CrossRef]

47. Nabekura, T.; Yamaki, T.; Hiroi, T.; Ueno, K.; Kitagawa, S. Inhibition of anticancer drug efflux transporter P-glycoprotein by rosemary phytochemicals. Pharmacol. Res. 2010, 61, 259-263. [CrossRef] [PubMed]

48. Mosmann, T. Rapid colorimetric assay for cellular growth and survival: Application to proliferation and cytotoxicity assays. J. Immunol. Methods 1983, 65, 55-63. [CrossRef] 
49. Ludescher, C.; Thalerd, J.; Drach, D.; Spitaler, M.; Gattringer, C.; Huber, H.; Hofmann, J. Detection of activity of P-glycoprotein in human tumor samples using rhodamine 123. Br. J. Haematol. 1992, 82, 161-168. [CrossRef] [PubMed]

50. Holló, Z.; Homolya, L.; Davis, C.W.; Sarkadi, B. Calcein accumulation as a fluorometric functional assay of the multidrug tranaporter. Biochim. Biophys. Acta 1994, 1191, 384-388. [CrossRef]

51. Twentyman, P.R.; Rhodes, T.; Rayner, S. A comparison of rhodamine 123 accumulation and efflux in cells with P-glycoprotein-mediated and MRP-associated multidrug resistance phenotypes. Eur. J. Cancer 1994, 30, 1360-1369. [CrossRef]

52. Olson, D.P.; Taylor, B.J.; Ivy, S.P. Detection of MRP functional activity: Calcein AM but not BCECF AM as a multidrug resistance-related protein (MRP1) substrate. Cytometry 2001, 46, 105-113. [CrossRef] [PubMed]

53. Glavinas, H.; von Richter, O.; Vojnits, K.; Mehn, D.; Wilhelm, I.; Nagy, T.; Janossy, J.; Krizbai, I.; Couraud, P.; Krajcsi, P. Calcein assay: A high-throughput method to assess P-gp inhibition. Xenobiotica 2011, 41, 712-719. [CrossRef] [PubMed]

54. Ford, J.M.; Hait, W.N. Pharmacology of drugs that alter multidrug resistance in cancer. Pharmacol. Rev. 1990, 42, 155-199. [PubMed]

55. Yuan, J.S.; Reed, A.; Chen, F.; Stewart, C.N., Jr. Statistical analysis of real-time PCR data. BMC Bioinformat. 2006, 7, 85. [CrossRef] [PubMed]

56. Zhao, L.; Wientjes, M.G.; Au, J.L.-S. Evaluation of combination chemotherapy: Integration of nonlinear regression, curve shift, isobologram, and combination index analyses. Clin. Cancer Res. 2004, 10, 7994-8004. [CrossRef] [PubMed]

57. Chou, T. Theoretical basis, experimental design, and computerized simulation of synergism and antagonism in drug combination studies. Pharmacol. Rev. 2006, 58, 621-681. [CrossRef] [PubMed]

58. Tang, Z.; Li, T.; Tong, Y.; Chen, X.; Chen, X.; Wang, Y.; Lu, J. A systematic review of the anticancer properties of compounds isolated from liquorice (Gancao). Planta Med. 2015, 81, 1670-1687. [PubMed]

59. You, M.; Kim, M.; Jeong, K.; Kim, E.; Kim, Y.; Kim, H. Loquat (Eriobotrya japonica) leaf extract inhibits the growth of MDA-MB-231 tumors in nude mouse xenografts and invasion of MDA-MB-231 cells. Nutr. Res. Pract. 2016, 10, 139-147. [CrossRef] [PubMed]

60. Eid, S.Y.; El-Readi, M.Z.; Wink, M. Digitonin synergistically enhances the cytotoxicity of plant secondary metabolites in cancer cells. Phytomedicine 2012, 19, 1307-1314. [CrossRef] [PubMed]

61. Wink, M. Evolutionary advantage and molecular modes of action of multi-component mixtures used in phytomedicine. Curr. Drug Metab. 2008, 9, 996-1009. [CrossRef] [PubMed]

62. Qiao, X.; Ji, S.; Yu, S.; Lin, X.; Jin, H.; Duan, Y.; Zhang, L.; Guo, D.; Ye, M. Identification of key licorice constituents which interact with cytochrome $\mathrm{p} 450$ : Evaluation by LC/MS/MS cocktail assay and metabolic profiling. AAPS J. 2014, 16, 101-113. [CrossRef] [PubMed]

63. Herrmann, F.; Wink, M. Synergistic interactions of saponins and monoterpenes in HeLa cells, Cos7 cells and in erythrocytes. Phytomedicine 2011, 18, 1191-1196. [CrossRef] [PubMed]

(C) 2018 by the authors. Licensee MDPI, Basel, Switzerland. This article is an open access article distributed under the terms and conditions of the Creative Commons Attribution (CC BY) license (http://creativecommons.org/licenses/by/4.0/). 